\title{
Effects of Yeast Culture and Galacto-Oligosaccharides on Ruminal Fermentation in Holstein Cows
}

\author{
B. Mwenya, ${ }^{1}$ B. Santoso, ${ }^{2}$ C. Sar, ${ }^{1}$ B. Pen, ${ }^{1}$ R. Morikawa, ${ }^{1}$ K. Takaura, ${ }^{1}$ \\ K. Umetsu, ${ }^{1}$ K. Kimura, ${ }^{3}$ and J. Takahashi ${ }^{1}$ \\ ${ }^{1}$ Department of Animal Science, Obihiro University of Agriculture and Veterinary Medicine, \\ 080-8555, Japan \\ ${ }^{2}$ Faculty of Animal Science, Papua University Jl, Gunung Salju, Amban Manokwari-Irian Jaya \\ Barat 98314, Indonesia \\ ${ }^{3}$ Yakult Central Institute for Microbiological Research, Tokyo 186-8650, Japan
}

\begin{abstract}
Four nonlactating, ruminally cannulated Holstein cows were used in a $4 \times 4$ Latin square design, balanced for residual effects, to evaluate the effects of supplementing dairy cow diets with yeast culture (Trichosporon sericeum; YC), galacto-oligosaccharides (GOS), or the mixture of YC and GOS on ruminal fermentation, microbial $\mathrm{N}$ supply, in situ degradation, and energy and nitrogen metabolism. Treatments were arranged in a $2 \times 2$ factorial as follows: 1) basal diet, 2) basal diet plus $10 \mathrm{~g} / \mathrm{d} \mathrm{YC}, 3$ ) basal diet plus $2 \%$ GOS, 4) basal diet plus a mixture of $10 \mathrm{~g} / \mathrm{d} \mathrm{YC}$ and $2 \%$ GOS. Nitrogen losses in urine were lower, and retained $\mathrm{N}$ was higher, for cows supplemented with a mixture of YC and GOS. Ruminal $\mathrm{pH}$ was lower in cows supplemented with GOS alone compared with other treatments. Total VFA concentration was higher in cows fed control and GOS-supplemented diets than in those fed YC containing diets. The molar proportion of propionate was higher, and the molar proportion of acetate was lower, in cows fed control diets. Microbial N supply was higher in cows fed control diets. There were no major positive effects of supplements observed in this study. However, supplementation of a mixture of YC and GOS had a tendency for synergistic effects on $\mathrm{N}$ metabolism and in situ degradation of a soluble fraction of oat straw DM and CP of concentrates compared with supplementation of $\mathrm{YC}$ or GOS alone.
\end{abstract}

(Key words: yeast culture, galacto-oligosaccharides, ruminal fermentation, cow)

Abbreviation key: DFM = direct-fed microbial, EMNS = efficiency of microbial N synthesis, GOS = galacto-oligosaccharide, $\mathbf{O R P}=$ oxidation reduction potential, $\mathbf{Y C}=$ yeast culture.

Received September 13, 2004.

Accepted December 10, 2004.

Corresponding author: J. Takahashi; e-mail: junichi@obihiro. ac.jp.

\section{INTRODUCTION}

Modern animal production requires the use of safe and effective feed additives as rumen manipulators to increase animal productivity. Of late, the use of antibiotics and growth promoters in animal production has been strongly discouraged in most nations. One of the potential alternatives for antibiotics are direct-fed microbials (DFM) also known as probiotics. Although the results are not consistent, DFM are known to improve the establishment of beneficial gut microflora and reduce the risk of acidosis (Ghorbani et al., 2002); increase milk production and weight gain (Yoon and Stern, 1995) as well as the stimulating cellulolytic and lactate-utilizing bacteria; increase fiber digestion; and increase flow of microbial protein from rumen (Martin and Nisbet, 1992; Newbold et al., 1996). Most of the work on yeast cultures (YC) has been performed with Saccharomyces cerevisiae strain, and only limited data are available on the effects of including a prebiotic (nondigestible dietary supplement that stimulates the activity of beneficial organisms), galacto-oligosaccharides (GOS), in ruminants. The inclusion of either YC of the strain Trichosporon sericeum or $\beta 1-4$ galacto-oligosaccharides in sheep diets resulted in reduced methane production and increased energy retention (Mwenya et al., 2004b). The addition of a mixture of YC and GOS might have a synergistic effect over the use of either YC or GOS alone. Therefore, the objective of the present study was to determine the effects of adding YC, GOS, or the mixture of YC and GOS on ruminal fermentation, microbial $\mathrm{N}$ supply, in situ degradability, and energy and $\mathrm{N}$ metabolism in dairy cows.

\section{MATERIALS AND METHODS}

\section{Cows, Design, and Treatments}

Four nonlactating, ruminally cannulated Holstein cows $(697 \pm 25 \mathrm{~kg})$ were used in a $4 \times 4$ Latin square design, balanced for residual effects, to investigate the effects of supplementing cow diets with YC, GOS, or 
Table 1. Ingredient and nutrient composition of total mixed diet.

\begin{tabular}{lc}
\hline Ingredient, \% of DM & \\
Alfalfa hay cubes & 35.0 \\
Oat straw & 35.0 \\
Corn & 7.20 \\
Rye & 5.10 \\
Wheat & 5.70 \\
Wheat bran & 3.90 \\
Corn gluten feed & 2.70 \\
Soybean meal (450 g of CP/kg) & 1.65 \\
Rapeseed meal & 0.45 \\
Beet pulp & 1.32 \\
Alfalfa meal & 1.35 \\
Calcium carbonate & 0.33 \\
Salt & 1.20 \\
Malt & 0.09 \\
Minerals and vitamins ${ }^{1}$ & 0.09 \\
Nutrient & \\
DM, \% & 89.4 \\
OM, \% & 92.8 \\
CP, \% & 13.9 \\
Ether extract, \% & 3.1 \\
NDF, \% & 38.6 \\
ADF, \% & 25.6 \\
Acid detergent lignin, $\%$ & 4.8 \\
Metabolizable energy, ${ }^{2}$ Mcal/kg of DM & 2.3 \\
\hline
\end{tabular}

${ }^{1} 34,350 \mathrm{IU}$ of vitamin A/kg, $6870 \mathrm{IU}$ of vitamin D3/ $\mathrm{kg}, 46 \mathrm{mg}$ of vitamin $\mathrm{E} / \mathrm{kg}, 229 \mathrm{mg} / \mathrm{kg}$ of $\mathrm{Zn}, 126 \mathrm{mg}$ of $\mathrm{Mn}, 69 \mathrm{mg} / \mathrm{kg}$ of Fe, 33 $\mathrm{mg} / \mathrm{kg}$ of Cu, $2.6 \mathrm{mg} / \mathrm{kg}$ of I, $0.8 \mathrm{mg} / \mathrm{kg}$ of Co, and $0.46 \mathrm{mg} / \mathrm{kg}$ of Se.

${ }^{2}$ Calculated using NRC (2001).

the mixture of YC and GOS. The ruminal cannulas measured $10 \mathrm{~cm}$ in diameter and were made of soft plastic. The surgical preparation of cows was done 6 mo before the start of the study at the Department of Large Animal Clinic Science, Obihiro University of Agriculture and Veterinary Medicine. Cows were confined by means of stanchions in 4 individual metabolism stalls in a monitor room with rubber-padded concrete flooring under controlled temperature $\left(21 \pm 2^{\circ} \mathrm{C}\right)$. The metabolism stalls were equipped with electrical powered mechanical device (Taikisha Co. Ltd., Sapporo, Japan) that separates feces and urine automatically. The experiment was conducted under the approval of Obihiro University of Agriculture and Veterinary Medicine Animal Care and Use Committee.

Cows were fed the experimental diet shown in Table 1 at a restricted level of $76 \mathrm{~g}$ of $\mathrm{DM} / \mathrm{kg} \mathrm{BW} \mathrm{BW}^{0.75}$ in 2 feedings at 0900 and $1600 \mathrm{~h}$. The 4 dietary treatments were 1) basal diet containing $35 \%$ oat straw, $35 \%$ alfalfa hay, and $30 \%$ concentrate on DM basis (control); 2) basal diet supplemented with $2 \%$ GOS, 3) basal diet with $10 \mathrm{~g} / \mathrm{d} \mathrm{YC}$, and 4) basal diet with a mixture of 10 $\mathrm{g} / \mathrm{d} \mathrm{YC}$ and $2 \% \mathrm{GOS} / \mathrm{kg}$ feed. Yeast culture of the strain Trichosporon sericeum was isolated from laban, a traditional fermented milk product from Yemen, at Obihiro University of Agriculture \& Veterinary Medicine Department of Microbiology. Arai et al. (2002) reported that the most abundant yeast strains isolated from la- ban were Trichosporon sericeum, Saccharomyces, and Candida kefyr (34, 21, and 21\%, respectively). The YC strain of Trichosporon sericeum was sent to Konno Biotechnological Company (Japan) for mass production. The GOS were synthesized enzymatically from lactose by transgalactosidase activity of $\beta$-galactosidases derived from Aspergillus oryzae or Streptococcus thermophilus by Yakult Company Limited (Tokyo, Japan). The structure and composition of GOS are presented in Table 2. The viability of the YC preparation was checked prior to the experiment, and results were in agreement with the stated quantity of colony-forming units. Yeast culture was blended with a placebo powder to supply $1 \times 10^{8} \mathrm{cfu} / \mathrm{g}$ of carrier. Cows on the control or GOS treatments received $10 \mathrm{~g} / \mathrm{d}$ placebo to eliminate the possibility of any yeast cells in the carrier. The duration of each experimental period was $27 \mathrm{~d}$, with 2 wk adaptation and $13 \mathrm{~d}$ of data collection.

At the end of periods 1, 2, and 3, ruminal contents were manually emptied and switched over within the square so that each cow started the next experimental period with rumen contents corresponding to the same treatment. This was done to minimize the possible residual effects from period to period, mostly encountered when using live microorganisms (Ghorbani et al., 2002).

\section{Measurements and Analyses}

Total tract digestibility was measured from d 15 to 19 by total feces collection. A representative fecal sample was taken each day and dried at $60^{\circ} \mathrm{C}$ for $72 \mathrm{~h}$; urine was collected in buckets with $20 \%$ (vol/vol) sulfuric acid, and samples were stored at $-20^{\circ} \mathrm{C}$. The DM (934.01), OM (942.05), and Kjeldahl N (988.05) of feed and fecal samples were determined by AOAC (1996) procedures. Determinations of NDF were done according to the methods described by Van Soest et al. (1991), and ADF and acid detergent lignin were according to AOAC 973.18 (1996). Both the NDF and ADF were measured on an ash-free basis. Concentrates were analyzed with $\alpha$-amylase (Wako \#CKF 0569; Wako Pure Chemical Industries, Osaka, Japan) without sodium sulfite according to Van Soest et al. (1991). Energy content in feed, feces, and freeze-dried urine were determined with an adiabatic bomb calorimeter (CA-4P; Shimadzu, Japan).

\section{Microbial N Supply}

Microbial N supply was measured from urinary excretion of the purine derivatives allantion and uric acid in urine samples collected during the digestibility trial (d 15 to 19) of each period; $10 \mathrm{~mL}$ was subsampled, acidified with $20 \%$ sulfuric acid, and diluted 3 times 
Table 2. Structure and composition of galacto-oligosaccharide (GOS; Oligomate 55) (Yakult Central Institute for Microbiological Research, Tokyo, Japan).

\begin{tabular}{llc}
\hline Component & Oligosaccharide structure & $\begin{array}{c}\text { Unit } \\
(\mathrm{g} / 100 \mathrm{~g})\end{array}$ \\
\hline Monosaccharide & $(\mathrm{Glc}, \mathrm{Gal})^{1}$ & 18.3 \\
Disaccharides & $\mathrm{Gal} \beta 1-4 \mathrm{Glc}$ & 22.2 \\
& $\mathrm{Gal} \beta 1-3 \mathrm{Glc}$ & 9.2 \\
& $\mathrm{Gal} \beta 1-2 \mathrm{Glc}$ & 3.8 \\
& $\mathrm{Gal} \beta 1-6 \mathrm{Glc}$ & 1.6 \\
Trisaccharides & Others & 2.0 \\
& Gal $\beta 1-4 \mathrm{Gal} \beta 1-4 \mathrm{Glc}$ & 12.2 \\
Tetrasaccharides & Gal $\beta 1-4 \mathrm{Gal} \beta 1-3 \mathrm{Glc}$ & 4.3 \\
& Others & 6.6 \\
& Gal $\beta 1-4 \mathrm{Gal} \beta 1-4 \mathrm{Gal} \beta 1-4 \mathrm{Glc}$ & 9.2 \\
Penta- and hexasaccharides & Gal $\beta 1-4 \mathrm{Gal} \beta 1-4 \mathrm{Gal} \beta 1-3 \mathrm{Glc}$ & 2.2 \\
Water & Others & 4.3 \\
\hline
\end{tabular}

${ }^{1} \mathrm{Glc}=$ Glucose $; \mathrm{Gal}=$ galactose.

with tap water to bring $\mathrm{pH}$ to $<3$. These samples were stored at $-20^{\circ} \mathrm{C}$ for allantoin and uric acid determination. Allantoin was analyzed according to Chen and Gomes (1995); uric acid was measured using a commercial kit (Uric Acid C test kit; Wako Pure Chemical Industries, Ltd.) according to Fujihara et al. (1987). The supply of microbial $\mathrm{N}(\mathrm{MN})$ was estimated by the urinary excretion of purine derivatives (PD) according to Chen and Gomes (1995):

$$
\begin{gathered}
\mathrm{Y}=0.85 \mathrm{X}+\left(0.385 \mathrm{BW}^{0.75}\right) \\
\mathrm{MN}(\mathrm{g} / \mathrm{d})=70 \mathrm{X} /(0.116 \times 0.83 \times 1000)=0.727 \mathrm{X}
\end{gathered}
$$

where $\mathrm{X}$ and $\mathrm{Y}$ are, respectively, the absorption and excretion of $\mathrm{PD}$ in $\mathrm{mmol} / \mathrm{d}$.

The $\mathrm{N}$ content of purines was $70 \mathrm{mg} / \mathrm{mmol}$; the ratio of purine $\mathrm{N}$ to total $\mathrm{N}$ in mixed rumen microbes was 0.116 (Chen and Gomes, 1995). Mean endogenous contribution of urinary purine derivative excretion was $0.385 \mathrm{mmol} / \mathrm{kg} \mathrm{BW}^{0.75}$ (Verbic et al., 1990), digestibility of microbial purines in the intestines was estimated at 0.83 (Chen and Gomes, 1995), and recovery of absorbed purines as urinary purine derivatives was assumed to be $85 \%$ (Verbic et al., 1990).

Efficiency of microbial N supply (EMNS) was calculated using the following formula:

$$
\text { EMNS }=\text { microbial } N(g / d) / D O M R
$$

where DOMR (digestible OM apparently fermented in the rumen $)=$ DOMI $($ digestible OM intake $) \times 0.65$ (ARC, 1990).

\section{Gaseous Exchange}

On d 20 to 23 of each experimental period, oxygen consumption and carbon dioxide and methane production for the 4 cows were monitored by an open circuit respiratory system using a hood over the animal's head (Takahashi et al., 1999). Oxygen and methane concentration in inlet air and exhaust gas from the ventilated hood were analyzed with a paramagnetic dispersive infrared methane analyzer (model Horiba VIA-300, VIA-500), respectively. Data were pooled into the computer (NEC PC-9801 VM) from the analyzer through an interface at 1-min intervals and then standardized automatically at $0^{\circ} \mathrm{C}, 101 \mathrm{kPa}$, and zero water vapor pressure. Heat production was calculated using Brouwer's equation (Brouwer, 1965).

\section{In Situ Degradability of Feed}

On d 24 to 26 of each experimental period, in situ degradability determination was conducted in all 4 cows. Samples of oat straw, alfalfa hay cubes, and concentrate were ground to pass through a $2-\mathrm{mm}$ screen for the determination of ruminal degradability of DM, $\mathrm{CP}$, and NDF. Five-gram samples of oat straw, alfalfa hay, and concentrates were placed in nylon bags $(9 \times$ $14 \mathrm{~cm} ; 35 \mu \mathrm{m}$ pore size) and incubated in duplicate in reverse order for $2,4,8,16,24,48$, and $72 \mathrm{~h}$ in the rumen. Following incubation, the bags were rinsed under tap water and machine-washed for 20 min to reduce potential microbial contamination and remove all adherent material. The bags and their contents were then dried in a forced-air oven at $60^{\circ} \mathrm{C}$ for $48 \mathrm{~h}$. Residues from the nylon bags at each incubation time were then analyzed for DM, CP, and NDF as described by AOAC 
(1996) and Van Soest et al. (1991). The degradation parameters of DM, CP, and NDF were computed using DUD (the derivative-free iterative method) in the nonlinear regression procedure (PROC NLIN) of SAS (1996). The generalized equation (Ørskov and McDonald, 1979) was

$$
\mathrm{P}=\mathrm{a}+\mathrm{b}\left(1-\mathrm{e}^{-\mathrm{ct}}\right)
$$

where $\mathrm{P}$ is the $\mathrm{DM}, \mathrm{CP}$, or $\mathrm{NDF}$ disappearance (\%) at time $\mathrm{t}, \mathrm{a}$ is the soluble fraction (\%), $\mathrm{b}$ is the slowly degradable fraction (\%), and $\mathrm{c}$ is the rate of degradation of the $\mathrm{b}$ fraction $(\% / \mathrm{h})$. Effective degradability (ED) of $\mathrm{DM}, \mathrm{CP}$, and NDF was then calculated according to the equation (Ørskov and McDonald, 1979):

$$
\mathrm{ED}=\mathrm{a}+\mathrm{bc} /(\mathrm{k}+\mathrm{c})
$$

where $\mathrm{k}$ is the rumen outflow rate assumed to be either 2 or $5 \% / \mathrm{h}$ describing 2 ruminal retention times (50 and $20 \mathrm{~h}$, respectively) and a, b, and c are as described previously.

\section{Ruminal Fermentation}

On d 27 of each period, rumen samples were drawn from all cows via the rumen cannula at 6 time intervals $(0,1,2,3,5$, and $7 \mathrm{~h}$ after the morning feeding). Samples were strained through 2 layers of cheesecloth, the $\mathrm{pH}$ and oxidation reduction potential (ORP) were recorded immediately using a pH-mV meter (HM-21P, Toa, Japan). For individual VFA determination, $3.0 \mathrm{~mL}$ of rumen fluid was centrifuged at $18,000 \times g$ at $2^{\circ} \mathrm{C}$ for 15 $\mathrm{min}$, and $0.8 \mathrm{~mL}$ of supernatant was deproteinized with $0.2 \mathrm{~mL}$ of $25 \%$ metaphosphoric acid and stored at $-20^{\circ} \mathrm{C}$ overnight. After thawing, the sample was centrifuged at $8000 \times g$ for $15 \mathrm{~min}$, and $0.5 \mathrm{~mL}$ of supernatant was added to $0.5 \mathrm{~mL}$ of internal standard (10 $\mathrm{m} M$ 2-ethylbutyric acid). Individual VFA were quantified by a gas chromatograph (GC-14A, Shimadzu, Japan) equipped with a capillary column $(30 \mathrm{~m} \times 0.53 \mathrm{~mm}$ i.d.; ULBON HR-52; Shinwa Chemical Industries) and a flame ionization detector. The gas chromatograph was operated under the following conditions: injector temperature, $190^{\circ} \mathrm{C}$; detector temperature, $280^{\circ} \mathrm{C}$; initial temperature, $70^{\circ} \mathrm{C}$; second temperature, $90^{\circ} \mathrm{C}(4 \mathrm{~min})$; final temperature, $180^{\circ} \mathrm{C}(3 \mathrm{~min})$. The carrier gas was He, being supplied at a flow rate of $20 \mathrm{~mL} / \mathrm{min}$. Ruminal ammonia $\mathrm{N}$ was determined by the microdiffusion method modified by Conway and O'Malley (1942).

\section{Protozoa Enumeration}

Ruminal fluid was collected $6 \mathrm{~h}$ after feeding during the last day of each collection period. One milliliter of the sample was diluted with $4 \mathrm{~mL}$ of methyl greenformalin-saline solution (35\% formaldehyde solution, $100 \mathrm{~mL}$; distilled water, $900 \mathrm{~mL}$; methyl green, $0.6 \mathrm{~g}$; sodium chloride, $8.0 \mathrm{~g}$ ), and ruminal ciliate protozoa enumeration was done $4 \mathrm{~h}$ later. The methyl greenformalin-saline solution was tightly sealed and stored in a dark room. Samples of ruminal juice fixed with methyl green-formalin-saline solution were counted for ciliate protozoa content using a Fuchs-Rosenthal counting chamber (EKDS, Tokyo, Japan) as described previously (Ogimoto and Imai, 1981).

\section{Statistical Analyses}

Statistical analyses for Latin square experiments using the GLM procedure of SAS (1996) examined the effects of cow, period, and supplementary treatment in the model. Data on ruminal fermentation parameters ( $\mathrm{pH}, \mathrm{ORP}$, ammonia $\mathrm{N}$, and VFA) as well as in situ degradability of each feedstuff for each nutrient at each sampling time were analyzed by the MIXED procedure of SAS (1996) for repeat measures. In case of significant differences in main effects, contrasts were evaluated, and least squares means were separated using the least significant differences. The overall least squares means were declared significant at $P<0.05$, and trends were discussed at $P<0.10$, unless otherwise stated.

\section{RESULTS AND DISCUSSION}

\section{Digestibility, $\mathrm{N}$, and Energy Use}

There were no significant differences observed for DM, CP, OM, and NDF digestibility between cows fed a control diet and those fed supplemented diets (Table 3). However, cows fed a YC-supplemented diet had numerically higher CP digestibility compared with those fed a GOS-supplemented diet. A number of studies (Mwenya et al., 2004a,b) with GOS supplementation in ruminants reported no differences in nutrient digestibility compared with nonsupplemented animals. Lack of responses in nutrient digestibility in ruminant diets supplemented with YC has also been reported (Williams et al., 1991). Microbial feed supplements may change bacteria numbers, which may influence the rate of fiber digestion, but not the digestibility of the diet, which is more related to the physicochemical structure of the feed (Hovell et al., 1986).

Daily $\mathrm{N}$ intake was similar among treatments because of the limited amounts of feed offered with no orts. There were no significant differences in fecal N losses between supplemented cows and those fed control diets. However, cows fed a GOS-supplemented diet had numerically higher $\mathrm{N}$ losses in feces than those fed a YC-supplemented diet. Urinary $\mathrm{N}$ losses were lower 
Table 3. Nutrient digestibility, $\mathrm{N}$ balance, and energy losses in Holstein cows fed a basal diet (control) or a basal diet supplemented with yeast culture (YC), galacto-oligosaccharides (GOS), or a mixture of YC and GOS. $^{1}$

\begin{tabular}{lccccc}
\hline & Control & GOS & YC & YC + GOS & SEM \\
\hline Digestibility & & & & & \\
DM, \% & 72.5 & 70.5 & 71.4 & 71.4 & 0.94 \\
OM, \% & 74.1 & 72.1 & 72.8 & 72.9 & 0.90 \\
CP, \% & 74.2 & 73.3 & 75.9 & 74.8 & 0.82 \\
NDF, \% & 63.8 & 60.7 & 60.8 & 61.9 & 1.30 \\
N balance & & & & \\
Intake, g/d & 228.1 & 228.1 & 228.1 & 228.1 & - \\
Feces, g/d & 58.6 & 60.9 & 54.9 & 57.7 & 1.84 \\
Urine, g/d & $149.8^{\mathrm{a}}$ & $149.2^{\mathrm{a}}$ & $145.3^{\mathrm{a}}$ & $122.4^{\mathrm{b}}$ & 7.65 \\
N retained, g/d & $19.7^{\mathrm{b}}$ & $18.0^{\mathrm{b}}$ & $27.9^{\mathrm{ab}}$ & $48.0^{\mathrm{a}}$ & 4.65 \\
Energy losses & & & & & \\
Feces, \% of GE intake & 28.0 & 28.1 & 27.9 & 28.6 & 0.86 \\
Urine, \% of GE intake & 3.7 & 3.5 & 3.2 & 3.4 & 0.27 \\
Methane, \% of GE intake & 5.99 & 6.11 & 6.48 & 6.63 & 0.19 \\
Heat, \% of GE intake & 46.9 & 47.6 & 46.5 & 46.8 & 0.66 \\
Retained, \% of GE intake & 15.4 & 14.7 & 15.9 & 14.6 & 1.22 \\
\hline
\end{tabular}

\footnotetext{
${ }^{\mathrm{a}, \mathrm{b}}$ Means within a row with different superscripts differ $(P<0.05)$

${ }^{1}$ Data presented are least squares means.

${ }^{2} \mathrm{GE}=$ Gross energy.
}

$(P<0.05)$ in cows fed a mixture of $\mathrm{YC}$ and GOS than those fed the control or other supplements. Consequently, retained $\mathrm{N}$ was higher $(P<0.05)$ in cows fed a mixture of YC and GOS supplements than those fed the control or GOS-supplemented diets.

Energy intakes were also similar among treatments, however, no significant effects were observed as heat, fecal, or urinary energy losses in cows fed control or other treatments. Methane production increased drastically after every feeding ( 0 and $7 \mathrm{~h}$ ) then decreased gradually with time post feeding. Cows fed control diets had numerically lower methane energy losses than those fed a mixture of YC and GOS supplements. Even the cows supplemented with GOS alone had numerically lower methane energy losses than the cows fed a mixture of YC and GOS. The results are contrary to the earlier work (Mwenya et al., 2004b), where methane production was reduced in sheep fed diets supple- mented with either $\mathrm{YC}$ of the strain Trichosporon sericem or GOS, and in steers fed GOS (Mwenya et al., 2005). Differences in these experiments such as type of feed offered, animal species, and age, even the mode of production (mass production vs. laboratory preparation) of $\mathrm{YC}$ might have contributed to the variation.

\section{Microbial N Supply}

Urinary purine derivative excretion and microbial $\mathrm{N}$ supply estimates are shown in Table 4 . The daily excretion of uric acid and allantoin were higher $(P<$ 0.001 and $P<0.01$, respectively) in cows fed control diets than in those supplemented with YC, GOS, or the mixture of $\mathrm{YC}$ and GOS. There was a tendency for higher uric acid excretion in cows fed a mixture of $\mathrm{YC}$ and GOS than in cows supplemented with either YC or GOS alone. The supplemented cows had lower $(P<$

Table 4. Effects of yeast culture (YC) and galacto-oligosacharides (GOS) supplementation on purine derivative excretion in dairy cows. ${ }^{1}$

\begin{tabular}{lrrrrr}
\hline Dependent variable & Control & GOS & YC & YC + GOS & SEM \\
\hline Urinary excretion & & & & & \\
Uric acid, mmol/d & $30.8^{\mathrm{c}}$ & $20.6^{\mathrm{d}}$ & $19.9^{\mathrm{d}}$ & $23.6^{\mathrm{d}}$ & 1.3 \\
Allantoin, mmol/d & $166.7^{\mathrm{a}}$ & $120.2^{\mathrm{b}}$ & $131.6^{\mathrm{b}}$ & $135.2^{\mathrm{b}}$ & 7.1 \\
Total, mmol/d & $197.5^{\mathrm{a}}$ & $140.8^{\mathrm{b}}$ & $151.5^{\mathrm{b}}$ & $158.8^{\mathrm{b}}$ & 8.1 \\
Absorption, mmol/d & $170.0^{\mathrm{a}}$ & $104.2^{\mathrm{b}}$ & $116.8^{\mathrm{b}}$ & $125.4^{\mathrm{b}}$ & 9.5 \\
Microbial N supply, g/d & $124.3^{\mathrm{a}}$ & $75.8^{\mathrm{b}}$ & $84.9^{\mathrm{b}}$ & $91.1^{\mathrm{b}}$ & 6.9 \\
Microbial N, g/kg of DOMR & $32.6^{\mathrm{a}}$ & $20.1^{\mathrm{b}}$ & $22.5^{\mathrm{b}}$ & $24.7^{\mathrm{b}}$ & 2.0 \\
\hline
\end{tabular}

${ }_{\mathrm{a}, \mathrm{b}, \mathrm{c}, \mathrm{d}}$ Means within a row with different superscripts $\operatorname{differ}\left({ }^{\mathrm{a}, \mathrm{b}} P<0.01\right.$; $\left.{ }^{\mathrm{c}, \mathrm{d}} P<0.001\right)$.

${ }^{1}$ Data presented are least squares means.

${ }^{2} \mathrm{DOMR}=$ Digestible OM apparently fermented in the rumen: DOMI $\times 0.65(\mathrm{ARC}, 1990)$, where DOMI $=$ digestible $\mathrm{OM}$ intake. 
Table 5. Ruminal DM and NDF degradability of oat straw in cows fed a basal diet (control) or a basal diet supplemented with yeast culture (YC), galacto-oligosaccharides (GOS), or a combination of YC and GOS. ${ }^{1}$

\begin{tabular}{llccccc}
\hline & Degradation $^{2}$ & Control & GOS & YC & YC + GOS & SEM \\
\hline $\mathrm{DM}$ & & & & & & \\
& $\mathrm{a}$ & $31.4^{\mathrm{b}}$ & $31.0^{\mathrm{b}}$ & $31.9^{\mathrm{b}}$ & $33.1^{\mathrm{a}}$ & 0.32 \\
& $\mathrm{~b}$ & 46.0 & 46.1 & 44.0 & 44.4 & 1.07 \\
& $\mathrm{c}$ & 0.05 & 0.05 & 0.05 & 0.04 & 0.01 \\
& $\mathrm{ED}_{0.02}$ & 64.2 & 64.0 & 63.0 & 62.1 & 1.55 \\
$\mathrm{NDF}$ & $\mathrm{ED}_{0.05}$ & 54.4 & 54.1 & 53.5 & 52.2 & \\
& $\mathrm{a}$ & & & & & \\
& $\mathrm{b}$ & 7.3 & 15.1 & 2.4 & 4.2 & 3.40 \\
& $\mathrm{c}$ & 03.8 & 59.1 & 66.4 & 69.1 & 0.008 \\
& $\mathrm{ED}^{3}{ }_{0.02}$ & 51.6 & 53.035 & 0.045 & 0.030 & 3.52 \\
& $\mathrm{ED}_{0.05}$ & 37.7 & 39.8 & 48.1 & 43.8 & 33.6 \\
\hline
\end{tabular}

${ }^{\mathrm{a}, \mathrm{b}}$ Means within a row for a nutrient with different superscripts differ $(P<0.05)$.

${ }^{1}$ Data presented are least squares means.

${ }^{2} \mathrm{P}=\mathrm{a}+\mathrm{b}\left(1-\mathrm{e}^{-\mathrm{ct}}\right)$, where $\mathrm{P}$ is the DM, CP, or NDF disappearance $(\%)$ at time $\mathrm{t}$, a is the soluble fraction $(\%), \mathrm{b}$ is the slowly degradable fraction $(\%)$, and $\mathrm{c}$ is rate of degradation of $\mathrm{b}$ fraction $(\% / \mathrm{h})$.

${ }^{3}$ Effective degradability, $\mathrm{ED}_{0.02}$ or $0.05=\mathrm{a}+(\mathrm{bc} /(\mathrm{k}+\mathrm{c}))$, where $\mathrm{k}$ is the rumen outflow rate assumed to be either 2 or $5 \% / \mathrm{h}$ describing 2 ruminal retention times (50 and $20 \mathrm{~h}$, respectively).

0.01) microbial $\mathrm{N}$ supply and EMNS (g of N/kg of digestible OM apparently fermented in the rumen) than the cows fed control diets. However, cows supplemented with the mixture of YC and GOS tended to have higher $(P=0.09)$ EMNS than cows supplemented with GOS alone. Our results concur with those of Yoon and Stern (1996) who reported a significant reduction in the efficiency of bacterial protein synthesis ( $\mathrm{g}$ of $\mathrm{N} / \mathrm{kg}$ of $\mathrm{OM}$ truly digested in the rumen) in Holstein cows supplemented with YC. In the present study, the reasons for a lower EMNS is unclear, but Yoon and Stern (1996) attributed it to an increase in ruminal OM digestion without a corresponding increase in bacterial protein synthesis.

\section{In Situ Degradability}

The percentage of soluble fraction of oat straw DM was higher $(P<0.05)$ in cows supplemented with a mixture of YC and GOS than in nonsupplemented cows or those supplemented with YC or GOS alone (Table 5 ). For the concentrates, the percentage of soluble $\mathrm{CP}$ fraction was also higher $(P<0.05)$ in cows supplemented with a mixture of $\mathrm{YC}$ and GOS than in those fed either YC or GOS-supplemented diets (Table 7). There were no other significant effects observed among treatments on the rate of degradation, percentage of slowly degradable fraction, or effective degradation at 2 and $5 \%$ outflow rates (Tables 5 through 7 ). Nonsignificant effects of YC supplementation in ruminant diets on in situ degradation of DM or fiber have been reported (Erasmus et al., 1992; Mir and Mir, 1994; Doreau and Jouany, 1998). On the contrary, Williams et al. (1991) reported a higher initial rate of degradation and suggested that it should have been due to a decrease in lag time in YC-supplemented cows.

\section{Ruminal Fermentation and Protozoa Number}

The sharp decrease in ruminal $\mathrm{pH}$ postfeeding could have been due to a rapid consumption rate of the feed. Ruminal $\mathrm{pH}$ was lower $(P<0.001)$ for the GOS-supplemented cows compared with those fed a control diet (Table 8). However, the supplementation of a mixture of $\mathrm{YC}$ and GOS in cows resulted in a higher $(P<0.05)$ ruminal $\mathrm{pH}$ than those supplemented with GOS alone. In our previous study, the supplementation of $\mathrm{YC}$ of the strain Trichosporon sericeum resulted in higher $\mathrm{pH}$ in sheep (Mwenya et al., 2004b). The supplementation of GOS, which is a readily fermentable carbohydrate, is likely to reduce the $\mathrm{pH}$ because of the production of lactic acid. Chonan et al. (1995) and Kikuchi et al. (1996) reported a decrease in cecal contents of rats fed GOS. It was demonstrated that lactic acid and succinic acids increased drastically in cecal contents of human flora-associated rats (Kikuchi et al., 1996) and the fecal contents of human volunteers (Ishikawa et al., 1995). Yeast cultures are known to stabilize ruminal $\mathrm{pH}$ by reducing lactic acid concentrations in the ruminal fluid (Williams et al., 1991); it is likely that the effect of GOS on ruminal $\mathrm{pH}$ was buffered by the $\mathrm{YC}$ in a mixed treatment. The ORP was numerically lower (92 units or 37\%) in cows fed the YC-supplemented diet than in cows fed the control diet. Lower ruminal ORP is desirable for fermentation, and YC may also stimulate rumen fermentation by scavenging excess oxygen from the rumen (Newbold et al., 1996). The oxygen uptake 
Table 6. Ruminal DM, CP, and NDF degradability of alfalfa hay in cows fed a basal diet (control) or a basal diet supplemented with yeast culture (YC), galacto-oligosaccharides (GOS), or a combination of YC and GOS. ${ }^{1}$

\begin{tabular}{lllllll}
\hline & Degradability $^{2}$ & Control & GOS & YC & YC + GOS & SEM \\
\hline $\mathrm{DM}$ & & & & & & \\
& $\mathrm{a}$ & 22.4 & 21.1 & 18.3 & 19.9 & 3.31 \\
& $\mathrm{~b}$ & 53.8 & 51.9 & 53.8 & 52.9 & 2.99 \\
& $\mathrm{c}$ & 0.125 & 0.160 & 0.140 & 0.170 & 0.028 \\
& $\mathrm{ED}_{0.02}$ & 68.6 & 67.2 & 66.4 & 64.7 & 2.90 \\
& $\mathrm{ED}_{0.05}$ & 60.6 & 60.6 & 59.8 & 57.1 & \\
$\mathrm{CP}$ & $\mathrm{a}$ & 26.3 & 31.9 & 26.8 & 32.3 & 5.28 \\
& $\mathrm{~b}$ & 64.3 & 57.7 & 62.7 & 56.8 & 5.40 \\
& $\mathrm{c}$ & 0.20 & 0.19 & 0.20 & 0.17 & 0.05 \\
& $\mathrm{ED}^{3}{ }_{0.02}$ & 84.7 & 84.0 & 83.5 & 80.3 & 3.13 \\
& $\mathrm{ED}$ & 77.7 & 77.3 & 76.4 & 72.5 & \\
$\mathrm{NDF}$ & $\mathrm{a}$ & -7.4 & -7.1 & -15.9 & -7.9 & 3.75 \\
& $\mathrm{~b}$ & 63.2 & 58.1 & 64.6 & 56.5 & 2.82 \\
& $\mathrm{c}$ & 0.088 & 0.106 & 0.132 & 0.086 & 0.03 \\
& $\mathrm{ED}_{0.02}$ & 44.1 & 41.8 & 40.2 & 37.9 & 3.91 \\
& $\mathrm{ED}_{0.05}$ & 32.9 & 32.4 & 31.0 & 27.8 & 3.40 \\
\hline
\end{tabular}

${ }^{1}$ Data presented are least squares means.

${ }^{2} \mathrm{P}=\mathrm{a}+\mathrm{b}\left(1-\mathrm{e}^{-\mathrm{ct}}\right)$, where $\mathrm{P}$ is the DM, CP, or NDF disappearance (\%) at time $\mathrm{t}$, a is the soluble fraction $(\%), \mathrm{b}$ is the slowly degradable fraction $(\%)$, and $\mathrm{c}$ is rate of degradation of $\mathrm{b}$ fraction $(\% / \mathrm{h})$.

${ }^{3}$ Effective degradability, $\mathrm{ED}_{0.02}$ or $0.05=\mathrm{a}+(\mathrm{bc} /(\mathrm{k}+\mathrm{c}))$, where $\mathrm{k}$ is the rumen outflow rate assumed to be either 2 or $5 \% / \mathrm{h}$ describing 2 ruminal retention times (50 and $20 \mathrm{~h}$, respectively).

capability varies significantly among yeast strains, and it is affected by the VFA (Lee et al., 2003).

Peak ruminal ammonia $\mathrm{N}$ concentration was observed at $2 \mathrm{~h}$ postfeeding for all treatments except the $\mathrm{YC}$ supplement, where the peak was at $3 \mathrm{~h}$ post feeding. The supplementation of YC, GOS, or the mixture of YC and GOS did not modify ammonia $\mathrm{N}$ concentration. Similar results (Newbold et al., 1995; Plata et al., 1994) have been reported on the effects of addition of $\mathrm{YC}$ in ruminant diets and also on the supplementation of GOS to sheep diets (Sar et al., 2004).

Total VFA production was lower in cows supplemented with $\mathrm{YC}$ and with a mixture of $\mathrm{YC}$ and GOS than those fed the control or GOS diets. Lower VFA production in cows fed YC-supplemented diets have been reported (Williams et al., 1991). The molar proportion of acetate was lower $(P<0.01)$, while the molar proportion of propionate was higher $(P<0.001)$, in cows

Table 7. Ruminal DM and CP degradability of concentrates in cows fed a basal diet (control) or a basal diet supplemented with yeast culture (YC), galacto-oligosaccharides (GOS), or the combination of YC and GOS. $^{1}$

\begin{tabular}{llccccc}
\hline & Degradability $^{2}$ & Control & GOS & YC & YC + GOS & SEM \\
\hline $\mathrm{DM}$ & & & & & & \\
& $\mathrm{a}$ & 24.1 & 24.6 & 21.9 & 26.7 & 4.49 \\
& $\mathrm{~b}$ & 73.0 & 70.4 & 72.3 & 67.8 & 2.64 \\
& $\mathrm{c}$ & 0.09 & 0.11 & 0.095 & 0.098 & 0.02 \\
& $\mathrm{ED}^{3}{ }_{0.02}$ & 83.4 & 84.2 & 81.9 & 81.9 & 3.98 \\
$\mathrm{CP}$ & $\mathrm{ED}_{0.05}$ & 70.6 & 73.0 & 70.1 & 69.7 & 3.59 \\
& $\mathrm{a}$ & $26.8^{\mathrm{a}}$ & $22.8^{\mathrm{b}}$ & $24.6^{\mathrm{b}}$ & $27.9^{\mathrm{a}}$ & 0.53 \\
& $\mathrm{~b}$ & 73.8 & 75.8 & 73.6 & 68.1 & 2.40 \\
& $\mathrm{c}$ & 0.050 & 0.050 & 0.045 & 0.045 & 0.007 \\
& $\mathrm{ED}_{0.02}$ & 75.6 & 73.3 & 72.7 & 74.7 & 1.77 \\
& $\mathrm{ED}_{0.05}$ & 60.9 & 58.3 & 57.7 & 60.2 & 2.3 \\
\hline
\end{tabular}

${ }^{\mathrm{a}, \mathrm{b}}$ Means within a row for a nutrient with different superscripts $\operatorname{differ}(P<0.05)$.

${ }^{1}$ Data presented are least squares means.

${ }^{2} \mathrm{P}=\mathrm{a}+\mathrm{b}\left(1-\mathrm{e}^{-\mathrm{ct}}\right)$, where $\mathrm{P}$ is the DM, CP, or NDF disappearance (\%) at time $\mathrm{t}$, a is the soluble fraction $(\%), \mathrm{b}$ is the slowly degradable fraction $(\%)$, and $\mathrm{c}$ is rate of degradation of $\mathrm{b}$ fraction $(\% / \mathrm{h})$.

${ }^{3}$ Effective degradability, $\mathrm{ED}_{0.02}$ or $0.05=\mathrm{a}+(\mathrm{bc} /(\mathrm{k}+\mathrm{c}))$, where $\mathrm{k}$ is the rumen outflow rate assumed to be either 2 or $5 \%$ h describing 2 ruminal retention times (50 and $20 \mathrm{~h}$, respectively). 
Table 8. Effects of yeast culture (YC) and galacto-oligosaccharides (GOS) supplementation on ruminal fermentation and protozoa numbers in Holstein cows. ${ }^{1}$

\begin{tabular}{|c|c|c|c|c|c|}
\hline & Control & GOS & $\mathrm{YC}$ & $\mathrm{YC}+\mathrm{GOS}$ & SEM \\
\hline Ruminal $\mathrm{pH}^{\mathrm{x}}$ & $6.72^{\mathrm{a}}$ & $6.56^{\mathrm{b}}$ & $6.67^{\mathrm{a}}$ & $6.65^{\mathrm{a}}$ & 0.03 \\
\hline Ruminal ORP ${ }^{2}$ & -248 & -250 & -340 & -242 & 41.5 \\
\hline Ammonia N, mg/L & 124 & 136 & 126 & 130 & 5.1 \\
\hline Total VFA, mM & $100^{\mathrm{a}}$ & $107^{\mathrm{a}}$ & $89.2^{\mathrm{b}}$ & $90.6^{\mathrm{b}}$ & 3.5 \\
\hline \multicolumn{6}{|l|}{$\begin{array}{l}\text { Molar proportion } \\
\text { of VFA (mol/100 mol) }\end{array}$} \\
\hline Acetate (A) & $67.7^{\mathrm{d}}$ & $71.4^{\mathrm{c}}$ & $72.9^{\mathrm{c}}$ & $73.6^{\mathrm{c}}$ & 0.88 \\
\hline Propionate (P) & $19.7^{\mathrm{e}}$ & $15.3^{\mathrm{f}}$ & $14.8^{\mathrm{f}}$ & $14.0^{\mathrm{f}}$ & 0.80 \\
\hline Butyrate & $9.77^{\mathrm{cd}}$ & $10.5^{\mathrm{c}}$ & $9.36^{\mathrm{d}}$ & $10.3^{\mathrm{c}}$ & 0.19 \\
\hline Isoacids $^{3}$ & $2.90^{\mathrm{e}}$ & $2.84^{\mathrm{e}}$ & $2.96^{\mathrm{e}}$ & $2.16^{\mathrm{f}}$ & 0.13 \\
\hline $\mathrm{A}: \mathrm{P}$ & $4.12^{\mathrm{c}}$ & $4.92^{\mathrm{d}}$ & $5.05^{\mathrm{d}}$ & $5.52^{\mathrm{d}}$ & 0.03 \\
\hline Protozoa, $\times 10^{3} / \mathrm{mL}$ & 210 & 283 & 247 & 289 & 32 \\
\hline
\end{tabular}

fed control diets compared with other treatments. Therefore, the acetate to propionate ratio was lower $(P$ $<0.01$ ) in cows fed control diets compared with other treatments. This result could partially explain the tendency for lower methane emission in cows fed control diets compared with diets supplemented with YC or the mixture of YC and GOS. Propionate production competes with methanogenesis for available hydrogen; therefore, increased molar production of propionate in control diets resulted in lower methane emission. Increased acetate production may be due to the increase in concentration of cellulolytic bacteria (Harrison et al., 1988) in the rumen of cows receiving YC-supplemented diets. The molar proportion of butyrate was higher $(P$ $<0.05)$ in GOS-supplemented cows and tended to be higher $(P=0.07)$ in cows supplemented with a mixture of YC and GOS than in cows fed control diets. Cows supplemented with a mixture of YC and GOS had a lower $(P<0.001)$ proportion of isoacids than cows fed the control diet or diets supplemented with YC or GOS alone. Yoon and Stern (1996) reported a lower molar percentage of isoacids in cows fed a mixture of yeast and fungal culture than for cows fed yeast or fungal culture alone.

Total protozoa count did not differ among dietary supplements; however, all supplemented cows had numerically higher protozoa counts than cows fed the control diets. A number of experiments have dealt with the effect of DFM on the protozoa population. In some cases (Newbold et al., 1995; Yoon and Stern, 1996), YC did not modify protozoa numbers; however, in other cases (Plata et al., 1994), protozoa number was increased. No data are available on the effects of supplementing GOS to ruminant diets on protozoa numbers.
In this experiment, GOS supplementation numerically increased protozoa numbers more than YC.

\section{CONCLUSIONS}

Results from this experiment reveal that the supplementation of GOS to Holstein cows may reduce the ruminal $\mathrm{pH}$, but the addition of $\mathrm{YC}$ together with GOS can help stabilize the ruminal $\mathrm{pH}$. Microbial N supply and EMNS was lower in supplemented cows; however, a mixture of $\mathrm{YC}$ and GOS produced numerically higher values than YC or GOS alone. There were no major positive effects of supplements observed in this study. However, supplementation of a mixture of YC and GOS had a tendency for synergistic effects on $\mathrm{N}$ metabolism and in situ degradation of soluble fractions of DM and $\mathrm{CP}$ of oat straw and concentrates, respectively, compared with YC or GOS alone.

\section{REFERENCES}

Agricultural Research Council. 1990. The Nutrient Requirements of Ruminant Livestock. Suppl. 1. Commonwealth Agricultural Bureaux, Slough, Farnham Royal, UK.

Arai, I., K. Nakajima, C. Maruyama, T. Nakamura, T. Toba, and T. Urashima. 2002. Microflora of microorganisma and several characteristics of laban, a traditional natural fermented milk in Yemen. Milk Sci. (Jpn.) 51:63-71.

Association of Official Analytical Chemists. 1996. Official Methods of Analysis. 16th ed. AOAC, Arlington, VA.

Brouwer, E. 1965. Report of sub-committee on constants and factors. Pages 441-443 in Proceedings of the Third EAAP Symp. on Energy Metabolism, Troon, Scotland, K. L. Blaxter, ed. Academic Press, London, UK.

Chen, X. B., and M. J. Gomes. 1995. Estimation of microbial protein supply to sheep and cattle based on urinary excretion of purine derivatives: An overview of technical details. International Feed Resource Unit, Rowett Research Institute, Aberdeen, UK. 
Chonan, O., K. Matsumoto, and M. Watanuki. 1995. Effect of galactooligosaccharides on calcium absorption and preventing bone loss in ovariectomized rats. Biosci. Biotechnol. Biochem. 59:236-239.

Conway, E. J., and E. O’Malley. 1942. Micro diffusion methods: Ammonia and urea using buffered absorbents (revised methods of ranges greater than $10 \mu \mathrm{g} \mathrm{N}$ ). Biochem. J. 36:655-661.

Doreau, M., and J. P. Jouany. 1998. Effect of a Saccharomyces cerevisiae culture on nutrient digestion in lactating dairy cows. J. Dairy Sci. 81:3214-3221.

Erasmus, L. J., P. M. Botha, and A. Kistner. 1992. Effect of yeast culture supplement on production, rumen fermentation, and duodenal nitrogen flow in dairy cows. J. Dairy Sci. 75:3056-3065.

Fujihara, T., E. R. Orskov, and P. J. Reeds. 1987. The effects of protein infusion on urinary excretion of purine derivatives in ruminants nourished by intragastric nutrition. J. Agric. Sci. (Camb.) 109:7-12.

Ghorbani, G. R., D. P. Morgavi, K. A. Beauchemin, and J. A. Z. Leedle. 2002. Effects of bacterial direct-fed microbials on ruminal fermentation, blood variables, and the microbial populations of feedlot cattle. J. Anim. Sci. 80:1977-1985.

Harrison, G. A., R. W. Hemken, K. A. Dawson, R. J. Harmon, and B. K. Barker. 1988. Influence of addition of yeast culture supplement to diets of lactating cows on ruminal fermentation and microbial population. J. Dairy Sci. 71:2967-2975.

Hovell, F. D., J. W. Deb, W. P. Ngambi, and D. J. Kyle. 1986. The voluntary intake of hay by sheep in relation to its degradability in the rumen as measured in nylon bags. Anim. Prod. 42:111-118.

Ishikawa, F., H. Takayama, K. Matsumoto, M. Ito, O. Chonan, Y. Deguchi, H. Kikuchi-Hayakawa, and M. Watanuki. 1995. Effects of $\beta 1$-4 linked galacto-oligosaccharides on human fecal microflora. Bifidus (Japanese) 9:5-18.

Kikuchi, H., C. Andrieux, M. Riottot, M. Bensaada, F. Popot, P. Beaumatin, and O. Szylit. 1996. Effect of two levels of transgalactosylated oligosaccharides intake in rats associated with human fecal microflora on bacterial glycolytic activity, end-product of fermentation and bacteria steroid transformation. J. Appl. Bacteriol. 80:439-446.

Lee, J. H., Y. B. Lim, K. M. Park, S. W. Lee, S. Y. Baig, and H. T. Shin. 2003. Factors affecting oxygen uptake by yeast Issatchenkia orientalis as microbial feed additive for ruminants. Asian-Australas. J. Anim. Sci. 16:1011-1014.

Martin, S. A., and D. J. Nisbet. 1992. Effects of direct-fed microbials on ruminal microbial fermentation. J. Dairy Sci. 75:1736-1744

Mir, Z., and P. S. Mir. 1994. Effect of the addition of live yeast (Saccharomyces cerevisiae) on growth and carcass quality of steers fed high-forage or high-grain diets and on feed digestibility and in situ degradability. J. Anim. Sci. 72:537-545.

Mwenya, B., B. Santoso, C. Sar, Y. Gamo, T. Kobayashi, I. Arai, and J. Takahashi. 2004b. Effects of including $\beta 1-4$ galacto-oligosaccharides, lactic acid bacteria or yeast culture on methanogenesis as well as energy and nitrogen metabolism in sheep. Anim. Feed Sci. Technol. 115:313-326.

Mwenya, B., C. Sar, B. Santoso, T. Kobayashi, R. Morikawa, K. Takaura, K. Umetsu, S. Kogawa, K. Kimura, H. Mizukoshi, and J. Takahashi. 2005. Comparing the effects of $\beta 1$-4 galacto-oligosac- charides and L-cysteine to monensin on energy and nitrogen utilization in steers fed a very high concentrate diet. Anim. Feed Sci. Technol. 118:19-30.

Mwenya, B., X. Zhou, B. Santoso, C. Sar, Y. Gamo, T. Kobayashi, and J. Takahashi. 2004a. Effects of probiotic-vitacogen and $\beta 1$ 4 galacto-oligosaccharides supplementation on methanogenesis and energy and nitrogen utilization in dairy cows. Asian-Australas. J. Anim. Sci. 17:349-354.

National Research Council. 2001. Nutrient Requiremnets of Dairy Cattle. 7th rev. ed. Natl. Acad. Sci., Washington, DC.

Newbold, C. J., R. J. Wallace, X. B. Chen, and F. M. McIntosh. 1995. Different strains of Saccharomyces cerevisiae differ in their effects on ruminal bacteria number in vitro and in sheep. J. Anim. Sci. 73:1811-1818.

Newbold, C. J., R. J. Wallace, and F. M. McIntosh. 1996. Mode of action of the yeast Saccharomyces cerevisiae as a feed additive for ruminants. Br. J. Nutr. 76:249-261.

Ogimoto, K., and S. Imai. 1981. Atlas of Rumen Microbiology. Japan Scientific Societies Press, Tokyo, Japan.

Ørskov, E. R., and I. McDonald. 1979. The estimation of protein degradability in the rumen from incubation measurements weighed according to rate of passage. J. Agric. Sci. (Camb.) 92:499-503.

Plata, P. F., M. G. D. Mendoza, J. R. Barcena-Gama, and M. S. Gonzalez. 1994. Effects of a yeast culture (Saccharomyces cerevisiae) on neutral detergent fiber digestion in steers fed oats straw based diets. Anim. Feed Sci. Technol. 49:203-210.

Sar, C., B. Santoso, B. Mwenya, Y. Gamo, T. Kobayashi, R. Morikawa, K. Kimura, H. Mizukoshi, and J. Takahashi. 2004. Manipulation of rumen methanogenesis by the combination of nitrate with $\beta 1$ 4 galacto-oligosaccharides or nisin in sheep. Anim. Feed Sci. Technol. 115:129-142.

SAS. 1996. User's Guide, Release 6.12. SAS Inst., Inc., Cary, NC.

Takahashi, J., A. S. Chaudhry, R. G. Beneke, and B. A. Young. 1999. An open-circuit hood system for gaseous exchange measurements in small ruminants. Small Rumin. Res. 32:31-36.

Van Soest, P. J., J. B. Robertson, and B. A. Lewis. 1991. Methods for dietary fiber, neutral detergent fiber, and non-starch polysaccharides in relation to animal nutrition. J. Dairy Sci. 74:35833597.

Verbic, J., X. B. Chen, N. A. MacLeod, and E. R. Orskov. 1990. Excretion of purine derivatives by ruminants: Effect of microbial nucleic acid infusion on purine derivatives excretion by steers. J. Agric. Sci. (Camb.) 114:243-248.

Williams, P. E., C. A. Tait, G. M. Innes, and C. J. Newbold. 1991. Effects of the inclusion of yeast culture (Saccharomyces cerevisiae plus growth medium) in the diet of dairy cows on milk yield and forage degradation and fermentation patterns in the rumen of steers. J. Anim. Sci. 69:3016-3026.

Yoon, I. K., and M. D. Stern. 1995. Influence of direct-fed microbials on ruminal fermentation and performance of ruminants: A review. Asian-Australas. J. Anim. Sci. 8:533-555.

Yoon, I. K., and M. D. Stern. 1996. Effects of Saccharomyces cerevisiae and Aspergillus oryzae cultures on ruminal fermentation in dairy cows. J. Dairy Sci. 79:411-417. 